\title{
CORRIGENDUM
}

\section{Luteolin uptake by Rhizobium meliloti: evidence for several steps including an active extrusion process}

\author{
C. Hubac, J. Ferran, A. Trémolières and A. Kondorosi
}

Microbiology (1994), 140, 2769-2774

In Table 3 (p. 2773), the last two lines of results were transposed. The correct version of the table is given below:

Table 3. Luteolin uptake and extrusion by intact bacteria exposed to different conditions or treatment

Luteolin extrusion was expressed as the percentage of luteolin taken up which was lost during the incubation in the fresh medium without luteolin. Values are means of five experiments $\pm \mathrm{SE}$.

\begin{tabular}{|c|c|c|c|}
\hline \multirow[t]{2}{*}{ Conditions* } & \multicolumn{2}{|c|}{$\begin{array}{c}\text { Luteolin uptake } \\
{\left[\mathrm{ng}(\mathrm{ml} \text { culture })^{-1}\right]}\end{array}$} & \multirow{2}{*}{$\begin{array}{c}\text { Luteolin } \\
\text { extrusion } \\
(\%)\end{array}$} \\
\hline & $\begin{array}{c}\text { After } 4 \mathrm{~h} \\
\text { incubation } \\
\text { with } \\
\text { luteolin }\end{array}$ & $\begin{array}{c}\text { After } 1 \text { h } \\
\text { more } \\
\text { without } \\
\text { luteolin }\end{array}$ & \\
\hline 1. Control $\left(30^{\circ} \mathrm{C}\right)$ & $95 \pm 6$ & $18 \pm 1$ & 81 \\
\hline $\begin{array}{l}\text { 2. Killed by heating at } \\
100^{\circ} \mathrm{C}\end{array}$ & $190 \pm 12$ & $170 \pm 20$ & $0 \cdot 1$ \\
\hline $\begin{array}{l}\text { 3. + Luteolin for } 4 \mathrm{~h} \text { at } \\
30^{\circ} \mathrm{C} \text {, then - luteolin } \\
\text { for } 1 \mathrm{~h} \text { at } 4{ }^{\circ} \mathrm{C}\end{array}$ & $95 \pm 6$ & $49 \pm 4$ & 48 \\
\hline $\begin{array}{l}\text { 4. }+ \text { Luteolin for } 4 \mathrm{~h} \text { at } \\
4{ }^{\circ} \mathrm{C} \text {, then }- \text { luteolin } \\
\text { for } 1 \mathrm{~h} \text { at } 4^{\circ} \mathrm{C}\end{array}$ & $164 \pm 10$ & $48 \pm 4$ & 71 \\
\hline $\begin{array}{l}\text { 5. + Luteolin and } \\
\mathrm{KCN} \text { for } 4 \mathrm{~h} \text {, then } \\
- \text { luteolin }+\mathrm{KCN} \text { for } \\
1 \mathrm{~h}\end{array}$ & $166 \pm 11$ & $63 \pm 5$ & 62 \\
\hline $\begin{array}{l}\text { 6. + Luteolin for } 4 \mathrm{~h} \\
\text { then - luteolin }+\mathrm{KCN} \\
\text { for } 1 \mathrm{~h}\end{array}$ & $95 \pm 6$ & $63 \pm 5$ & 34 \\
\hline
\end{tabular}

* 1. Bacteria were incubated at $30^{\circ} \mathrm{C}$ with luteolin $(10 \mu \mathrm{M})$ for $4 \mathrm{~h}$, then, for the analyses of luteolin extrusion, bacteria were pelleted and resuspended in fresh TA medium in the bacterial pellet. 2 . Bacteria were killed by heating at $100^{\circ} \mathrm{C}$ for $30 \mathrm{~min}$ and then incubated at $30^{\circ} \mathrm{C}$ with luteolin $(10 \mu \mathrm{M})$ for $4 \mathrm{~h}$. Luteolin extrusion was studied at $30^{\circ} \mathrm{C}$. 3 . Bacteria were incubated at $30^{\circ} \mathrm{C}$, and the luteolin extrusion was analysed at $4{ }^{\circ} \mathrm{C}$. 4. Bacteria were incubated at $4{ }^{\circ} \mathrm{C}$ with luteolin $(10 \mu \mathrm{M})$ for $4 \mathrm{~h}$; luteolin extrusion was analysed at $4{ }^{\circ} \mathrm{C}$. 5 . Bacteria were incubated with $\mathrm{KCN}(10 \mathrm{mM})$ and luteolin $(10 \mu \mathrm{M})$ for $4 \mathrm{~h}$; luteolin extrusion was analysed with $\mathrm{KCN}(10 \mathrm{mM})$. 6. Bacteria were incubated at $30^{\circ} \mathrm{C}$ and luteolin extrusion was analysed in the presence of $\mathrm{KCN}(10 \mathrm{mM})$. 